\title{
MODEL PEMBELAJARAN TEMATIK ANAK USIA DINI DALAM KURIKULUM 2013
}

\author{
Oleh : Saptiani \\ (Mahasiswa Pasca Sarjana Pendidikan Guru Raudhatul Athfal \\ UIN Sunan Kalijaga Yogyakarta)
}

\begin{abstract}
Abstrak
Kurikulum adalah seperangkat rencana dan pengaturan mengenai tujuan, isi, dan bahan pelajaran serta cara yang digunakan sebagai pedoman penyelenggaraan kegiatan pembelajaran untuk mencapai tujuan pendidikan tertentu. Karakteristik kurikulum 2013 adalah salah satunya tematik. Model pembelajaran tematik sejatinya adalah model pembelajaran terpadu yang menggabungkan berbagai mata pelajaran untuk dijadikan satu keutuhan dalam satu tema. namun, mengingat bahwasanya dalam pendidikan anak usia dini tidak memiliki mata pelajaran, maka tematik disini adalah mengaitkan satu tema dengan seluruh perkembangan anak usia dini yang berdasarkan kurikulum 2013 ada 6 aspek perkembangan yaitu spiritual, sosial emosional, kognitif, bahasa, keterampilan dan terakhir adalah seni. Hal yang harus diperhatikan dalam model pembelajaran tematik adalah tema yang diangkat sesuai dengan berbagai macam pengalaman siswa dan lingkungannya.
\end{abstract}

Kata Kunci: Pembelajaran tematik, kurikulum 2013, anak usia dini

\section{Pendahuluan}

Pendidikan sebagai gejala universal pada masyarakat manusia adalah merupakan usaha untuk membimbing dan mengembangkan anak didik dari makhluk alamiyah menjadi makhluk budaya. Dengan pendidikan potensi-potensi atau bakat-bakat yang dimiliki anak didik dapat dikembangkan secara nyata. Hal tersebut menjadikan ilmu pendidikan telah berkembang pesat dan terspesialisasi salah satu diantaranya ialah Pendidikan Anak Usia Dini (PAUD) yang membahas pendidikan untuk anak usia 0-6 tahun

\footnotetext{
Sebagaimana tercantum dalam Undang-undang Nomor 146 Tahun 2014 tentang sistem Pendidikan Nasional Bab I
}

Pasal 1 Menyatakan bahwa: "Pendidikan anak usia dini adalah merupakan suatu upaya pembinaan yang ditujukan kepada anak sejak lahir sampai dengan usia 6 tahun yang dilakukan melalui pemberian stimulus pendidikan untuk membantu perkembangan, pertumbuhan, baik jasmani maupun rohani sehingga anak memiliki kesiapan memasuki pendidikan lebih lanjut".

Anak usia TK/RA berada pada tahapan operasi konkrit. Pada rentang usia tersebut anak mulai menunjukkan prilaku belajar sebagai berikut : 1) Mulai memandang dunia secara objektif, bergeser dari satu aspek situasi kepada aspek lain secara reflektif dan memandang unsur-unsur secara serentak, 2) mulai berpikir secara operasional, 3) 
menggunakan cara berpikir operasional untuk mengklasifikasikan benda-benda, 4) membentuk dan menggunakan keterhubungan aturan-aturan, prinsip ilmiah sederhana, dan menggunakan hubungan sebab akibat, dan 5) memahami konsepkonsep substansi, volume zat cair, panjang, lebar, luas dan berat. (Trianto, 2013:10)

Berdasarkan tahapan perkembangan berpikir tersebut, kecenderungan belajar anak usia TK/RA memiliki tiga ciri, yaitu: konkret, integratif, hierarkis. Dengan demikian, dalam mengembangkan model pembelajaran bagi PAUD harus memerhatikan karakteristik anak dan kompetensi yang akan dicapai, interaksi dalam proses pembelajaran, alat/media, dan penilaian. Ada banyak model pembelajaran yang dapat dikembangakan dan diterapkan di TK/RA. Namun, yang terpenting dalam mengembangkan model pembelajaran di PAUD harus memerhatikan karakteristik anak dan kompetensi yang akan dicapai, interaksi dalam proses pembelajaran, alat/media, dan penilaian. Tetapi berdasarkan sifat dan karakter anak usia dini, maka pembelajaran di TK/RA bersifat Tematik yang dilakukan secara integratif, artinya bahwa pembelajaran di TK/RA tidak bisa dilakukan dengan metode tunggal. Itulah sebabnya, model pembelajaran yang dikenalkan adalah yang bersifat paduan (Integral).
Model pembelajaran Tematik pada hakikatnya merupakan model pembelajaran terpadu, yaitu suatu pendekatan pembelajaran yang memungkinkan peserta didik baik secara individual maupun kelompok aktif mencari, menggali, mengeksplorasi dan menemukan konsep serta prinsip secara holistik dan auntentik. Dan berkesinambungan Pembelajaran ini merupakan model yang mecoba memadukan beberapa pokok bahasan dalam suatu tema tertentu. Serta diharapkan siswa lebih memiliki kedalaman wawasan materi dengantingkat keterampilan dan pengetahuan yang beragam dan kompleks (multiple knowladge) serta tidak terpecah-pecah.

\section{Menurut Kamus Besar Bahasa}

Indonesia, kurikulum adalah perangkat mata pelajaran yang diajarkan pada lembaga pendidikan. (Departemen Pendidikan Nasional, 2008:1429). Adapun kurikulum berdasarkan Peraturan Menteri Pendidikan dan Kebudayaan Republik Indonesia Nomor 146 Tahun 2014 tentang kurikulum 2013 Pendidikan Anak Usia Dini adalah seperangkat rencana dan pengaturan mengenai tujuan, isi, dan bahan pelajaran serta cara yang digunakan sebagai pedoman penyelenggaraan kegiatan pembelajaran untuk mencapai tujuan pendidikan tertentu. Berdasarkan pengertian tersebut, terdapat dua dimensi kurikulum. Dimensi pertama adalah rencana dan pengaturan mengenai tujuan, isi, 
dan bahan pelajaran, sedangkan yang kedua adalah cara yang digunakan untuk kegiatan pembelajaran. Kurikulum 2013 Pendidikan Anak Usia Dini yang diberlakukan mulai tahun ajaran 2014/2015 memenuhi kedua dimensi tersebut.

Pada pendidikan anak usia dini kurikulum yang digunakan adalah berbentuk tema, dimana guru secara bersama menentukan tema yang cocok untuk anak yang disesuaikan dengan lingkungan lembaga. Hal tersebut juga sesuai dengan Peraturan Menteri Pendidikan dan Kebudayaan Republik Indonesia Nomor 146 Bab 15 pasal 9 tentang Standar Isi kurikulum 2013 adalah

1. Lingkup materi Standar Isi meliputi program pengembangan yang disajikan dalam bentuk tema dan sub tema

2. Tema dan sub tema sesuai dengan karakteristik, kebutuhan, tahap perkembangan anak, dan budaya lokal

3. Pelaksanaan tema dan sub tema dilakukan dalam kegiatan pengembangan melalui bermain dan pembiasaan

4. Tema dan sub tema dikembangkan dengan memuat unsur-unsur nilai agama dan moral, kemampuan berpikir, kemampuan berbahasa, kemampuan sosial emosional, kemampuan fisikmotorik, serta apresiasi terhadap seni

\section{Pembahasan}

\section{Kurikulum 2013}

\section{A. Pengertian Kurikulum}

Kurikulum adalah seperangkat rencana dan pengaturan mengenai tujuan, isi, dan bahan pelajaran serta cara yang digunakan sebagai pedoman penyelenggaraan kegiatan pembelajaran untuk mencapai tujuan pendidikan tertentu. Berdasarkan pengertian tersebut, terdapat dua dimensi kurikulum. Dimensi pertama adalah rencana dan pengaturan mengenai tujuan, isi, dan bahan pelajaran, sedangkan yang kedua adalah cara yang digunakan untuk kegiatan pembelajaran. Kurikulum 2013 Pendidikan Anak Usia Dini yang diberlakukan mulai tahun ajaran 2014/2015 memenuhi kedua dimensi tersebut.

\section{B. Kerangka Dasar Kurikulum 2013 \\ 1) Landasaan Filosofis}

Kurikulum 2013 pendidikan Anak Usia Dini dikembangkan dengan sejumlah lamdasan filosofis yang memberikan dasar bagi pengembangan seluruh potensi anak agar menjadi manusia Indonesia berkualitas sebagaimana yang tercantum dalam tujuan pendidikan masional.

Berdasarkan hal tersebut, kurikulum 2013, kurikulum 2013 Pendidikan Anak Usia Dini dikembangkan dengan menggunakan landasan filosofis sebagai berikut.

a. Pendidikan berakar pada budaya bangsa untuk membangun kehidupan bangsa masa kini dan masa mendatang. Pandangan ini menjadikan kurikulum 
2013 pendidikan Anak Usia Dini dikembangkan berdasarkan budaya bangsa Indonesia yang beragam dengan prinsip Bhineka Tunggal Ika, sehingga pendidikan di arahkan untuk membangun kehidupan masa kini, dan untuk membangun dasar bagi kehidupan bangsa yang lebih baik di masa depan. Sehubungan dengan itu, kurikulum 2013 Anak Usia Dini di rancang untuk dapat memberikan pengalaman belajar bagi anak agar mereka bisa memiliki landasan untuk menguasai kompetensi yang diperlukan bagi kehidupan di masa kini dan masa deepan, serta mengembangkan kemampuan sebagai pewaris budaya bangsa yang kreatif dan peduli terhadap permasalahan masyarakat dan bangsa.

b. Anak adalah pewaris budaya bangsa yang kreatif. Menurut pandangan filosofi ini, prestasi bangsa di berbagai bidang kehidupan di masa lampau adalah sesuatu yang harus termuat dalam isi kurikulum untuk memberi inspirasi dan rasa bangga pada anak. Kurikulum 2013 Pendidikan Anak Usia Dini memposisikan keunggulan budaya untuk menimbulkan rasa bangga yang tercermin, dalam kehidupan pribadi, bermasyarakat, dan berbangsa.

c. Dalam proses pendidikan, anak usia dini membutuhkan keteladanan, motivasi, pengayoman/perlindungan, dan pengawasan secara berkesinambungan sebagaimana dicontohkan oleh Ki Hajar Dewantara dalam filosofi: ing ngarso sung tulodo, ing madya mangun karso, tut wuri handayani.

d. Usia dini adalah masa ketika anak menghabiskan sebagian besar waktu untuk bermain. Karenanya pembelajaran pada PAUD dilaksanakan melalui bermain dan kegiatan-kegiatan yang mengandung prinsip bermain.

\section{2) Landasan Sosiologis}

Kurikulum 2013 Pendidikan Anak Usia Dini dikembangkan sesuai dengan tuntutan dan norma-norma yang berlaku di masyarakat setempat. Masyarakat Indonesia adalah masyarakat yang sangat beragam. Satuan PAUD merupakan representasi dari masyarakat yang beragam baik dari aspek strata sosial-ekonomi, budaya, etnis, agama, kondisi fisik maupun mental. Untuk mengakomodasi keberagaman itu, Kurikulum 2013 Pendidikan Anak Usia Dini dikembangkan secara inklusif untuk memberi dasar terbentuknya sikap saling menghargai dan tidak membeda-bedakan.

\section{3) Landasan Psiko-Pedagogis}

Kurikulum 2013 Pendidikan Anak Usia Dini dikembangkan dengan mengacu pada cara mendidik anak sebagai individu yang unik, memiliki kecepatan perkembangan yang berbeda, dan belum mencapai masa 
operasional konkret, dan karenanya digunakan pendekatan pembelajaran yang sesuai dengan tahapan perkembangan dan potensi setiap anak.

\section{4) Landasan Teoritis}

Kurikulum 2013 Pendidikan Anak Usia Dini dikembangkan dengan mengacu pada teori pendidikan berbasis standar dan kurikulum berbasis kompetensi. Pendidikan berbasis standar menetapkan adanya standar nasional sebagai kualitas minimal penyelenggaraan pendidikan. Standar tersebut terdiri dari standar tingkat pencapaian perkembangan anak, standar isi, standar proses, standar penilaian pendidikan, standar pendidik dan tenaga kependidikan, standar sarana dan prasarana, standar pengelolaan, dan standar pembiayaan. Proses pengembangan kurikulum secara langsung berlandaskan pada empat standar yakni standar tingkat pencapaian perkembangan anak, standar isi, standar proses, dan standar penilaian pendidikan. Sementara itu, empat standar lainnya dikembangkan lebih lanjut untuk mendukung implementasi kurikulum.

Kurikulum berbasis kompetensi dirancang untuk memberikan pengalaman belajar seluas-luasnya bagi anak untuk mengembangkan kemampuan yang berupa sikap, pengetahuan, dan keterampilan yang direfleksikan dalam kebiasaan berpikir dan bertindak. Kurikulum 2013 Pendidikan
Anak Usia Dini menerapkan pembelajaran dalam bentuk pemberian pengalaman belajar langsung kepada anak yang dirancang sesuai dengan latar belakang, karakteristik, dan usia anak.

\section{5) Landasan Yuridis}

Landasan yuridis Kurikulum 2013 Pendidikan Anak Usia Dini adalah:

1. Undang-Undang Dasar Negara Republik Indonesia Tahun 1945;

2. Undang-Undang Nomor 20 Tahun 2003 tentang Sistem Pendidikan Nasional;

3. Undang-undang Nomor 17 Tahun 2005 tentang Rencana Pembangunan Jangka Panjang Nasional, beserta segala ketentuan yang dituangkan ke dalam Rencana Pembangunan Jangka Menengah Nasional;

4. Peraturan Pemerintah Nomor 19 Tahun 2005 tentang Standar Nasional Pendidikan sebagaimana telah diubah dengan Peraturan Pemerintah Nomor 32 Tahun 2013 tentang Perubahan Atas Peraturan Pemerintah Nomor 19 Tahun 2005 tentang Standar Nasional Pendidikan; dan

5. Peraturan Presiden Nomor 60 Tahun 2013 Tentang Pengembangan Anak Usia Dini Holistik-Integratif.

\section{Kompetensi Inti Pendidikan Anak Usia Dini}


Kompetensi Inti (KI) pada Kurikulum 2013 Pendidikan Anak Usia Dini merupakan tingkat kemampuan untuk mencapai STPP yang harus dimiliki peserta didik PAUD pada usia 6 tahun. Jadi Kompetensi Inti merupakan operasionalisasi dari STPP dalam bentuk kualitas yang harus dimiliki anak dengan berbagai kegiatan pembelajaran melalui bermain yang dilakukan di satuan PAUD. Kualitas tersebut berisi gambaran mengenai kompetensi utama yang dikelompokkan ke dalam :

1. Kompetensi Inti-1 (KI-1) untuk kompetensi inti sikap spiritual.

2. Kompetensi Inti-2 (KI-2) untuk kompetensi inti sikap sosial.

3. Kompetensi Inti-3 (KI-3) untuk kompetensi inti pengetahuan.

4. Kompetensi Inti-4 (KI-4) untuk kompetensi inti keterampilan.

Kompetensi Dasar merupakan tingkat kemampuan dalam konteks muatan pembelajaran, tema pembelajaran, dan pengalaman belajar yang mengacu pada Kompetensi Inti. Rumusan Kompetensi Dasar dikembangkan dengan memperhatikan karakteristik dan kemampuan awal anak serta tujuan setiap program pengembangan. Kompetensi Dasar dibagi menjadi empat kelompok sesuai dengan pengelompokkan kompetensi inti yaitu: !
1. Kelompok 1: kelompok Kompetensi Dasar sikap spiritual dalam rangka menjabarkan KI-1;

2. Kelompok 2: kelompok Kompetensi Dasar sikap sosial dalam rangka menjabarkan KI-2;

3. Kelompok 3: kelompok Kompetensi Dasar pengetahuan dalam rangka menjabarkan KI-3; dan

4. Kelompok 4: kelompok Kompetensi Dasar keterampilan dalam rangka menjabarkan KI-4.

Uraian dari setiap Kompetensi Dasar untuk setiap kompetensi inti adalah sebagai berikut: (Peraturan Menteri Pendidikan dan Kebudayaan Nomor 146 Tahun 2013 lampiran 1: 6-8)

\begin{tabular}{|l|l|}
\hline \multicolumn{1}{|c|}{$\begin{array}{c}\text { KOMPETENSI } \\
\text { INTI }\end{array}$} & \multicolumn{1}{c|}{$\begin{array}{c}\text { KOMPETENSI } \\
\text { DASAR }\end{array}$} \\
\hline $\begin{array}{l}\text { KI-1. Menerima } \\
\text { ajaran agama } \\
\text { yang dianutnya }\end{array}$ & $\begin{array}{l}\text { 1.1. Mempercayai } \\
\text { adanya Tuhan melalui } \\
\text { ciptaan-Nya }\end{array}$ \\
\cline { 2 - 2 } $\begin{array}{l}\text { 1.2. Menghargai diri } \\
\text { sendiri, orang lain, dan } \\
\text { lingkungan sekitar } \\
\text { sebagai rasa syukur } \\
\text { kepada Tuhan }\end{array}$ \\
\hline $\begin{array}{l}\text { KI-2. Memiliki } \\
\text { perilaku hidup } \\
\text { sehat, rasa ingin } \\
\text { tahu, kreatif dan } \\
\text { estetis, percaya } \\
\text { diri, disiplin, } \\
\text { mandiri, peduli, } \\
\text { mampu } \\
\text { menghargai dan } \\
\text { toleran kepada } \\
\text { orang lain, } \\
\text { mampu } \\
\text { menyesuaikan }\end{array}$ & $\begin{array}{l}\text { 2.1. Memiliki perilaku } \\
\text { yang mencerminkan }\end{array}$ \\
$\begin{array}{l}\text { hidup sehat } \\
\text { yang mencerminkan } \\
\text { sikap ingin tahu }\end{array}$ \\
$\begin{array}{l}\text { 2.3. Memiliki perilaku } \\
\text { yang mencerminkan } \\
\text { sikap kreatif }\end{array}$ \\
\hline
\end{tabular}




\begin{tabular}{|c|c|}
\hline $\begin{array}{l}\text { diri, jujur, } \\
\text { rendah hati dan } \\
\text { santun dalam } \\
\text { berinteraksi } \\
\text { dengan } \\
\text { keluarga, } \\
\text { pendidik, dan } \\
\text { teman }\end{array}$ & $\begin{array}{l}\text { 2.4. Memiliki perilaku } \\
\text { yang mencerminkan } \\
\text { sikap estetis } \\
\text { 2.5. Memiliki perilaku } \\
\text { yang mencerminkan } \\
\text { sikap percaya diri } \\
\text { 2.6. Memiliki perilaku } \\
\text { yang mencerminkan } \\
\text { sikap taat terhadap aturan } \\
\text { sehari-hari untuk melatih } \\
\text { kedisiplinan } \\
\text { 2.7. Memiliki perilaku } \\
\text { yang mencerminkan } \\
\text { sikap sabar (mau } \\
\text { menunggu giliran, mau } \\
\text { mendengar ketika orang } \\
\text { lain berbicara) untuk } \\
\text { melatih kedisiplinan } \\
\text { 2.8. Memiliki perilaku } \\
\text { yang mencerminkan } \\
\text { kemandirian } \\
\text { 2.13.Memiliki perilaku } \\
\text { yang mencerminkan } \\
\text { sikap jujur } \\
\text { 2.9. Memiliki perilaku } \\
\text { yang mencerminkan } \\
\text { sikap peduli dan mau } \\
\text { membantu jika diminta } \\
\text { bantuannya } \\
\text { 2.10.Memiliki perilaku } \\
\text { yang mencerminkan } \\
\text { sikap menghargai dan } \\
\text { toleran kepada orang lain } \\
\text { 2.11.Memiliki perilaku } \\
\text { yang dapat menye- } \\
\text { suaikan diri } \\
\text { yang mencerminkan } \\
\text { sikap tanggungjawab } \\
\end{array}$ \\
\hline
\end{tabular}

\begin{tabular}{|c|c|}
\hline & $\begin{array}{l}\text { 2.14.Memiliki perilaku } \\
\text { yang mencerminkan } \\
\text { sikap rendah hati dan } \\
\text { santun kepada orang tua, } \\
\text { pendidik, dan teman }\end{array}$ \\
\hline $\begin{array}{l}\text { KI-3. Mengenali } \\
\text { diri, keluarga, } \\
\text { teman, pendidik, } \\
\text { lingkungan } \\
\text { sekitar,agama,te } \\
\text { knologi, seni, } \\
\text { dan budaya di } \\
\text { rumah, tempat } \\
\text { bermain dan } \\
\text { satuan PAUD } \\
\text { dengan cara: } \\
\text { mengamati } \\
\text { dengan indera } \\
\text { (melihat, } \\
\text { mendengar, } \\
\text { menghidu, } \\
\text { merasa, } \\
\text { meraba); } \\
\text { menanya; } \\
\text { mengumpulkan } \\
\text { informasi; } \\
\text { menalar; dan } \\
\text { mengomunikasi } \\
\text { kan melalui } \\
\text { kegiatan } \\
\text { bermain }\end{array}$ & $\begin{array}{l}\text { 3.2. Mengenal perilaku } \\
\text { baik sebagai cerminan } \\
\text { akhlak mulia } \\
\text { 3.3. Mengenal anggota } \\
\text { tubuh, fungsi, dan } \\
\text { gerakannya untuk } \\
\text { pengembangan motorik } \\
\text { kasar dan motorik halus } \\
\text { 3.4. Mengetahui cara } \\
\text { hidup sehat } \\
\text { 3.5. Mengetahui cara } \\
\text { memecahkan masalah } \\
\text { sehari-hari dan } \\
\text { berperilaku kreatif } \\
\text { 3.6. Mengenal benda- } \\
\text { benda disekitarnya } \\
\text { (nama, warna, bentuk, } \\
\text { ukuran, pola, sifat, suara, } \\
\text { tekstur, fungsi, dan ciri- } \\
\text { ciri lainnya) } \\
\text { 3.7. Mengenal } \\
\text { lingkungan sosial } \\
\text { (keluarga, teman, tempat } \\
\text { tinggal, tempat ibadah, } \\
\text { budaya, transportasi) } \\
\text { 3.8. Mengenal } \\
\text { lingkungan alam (hewan, } \\
\text { tanaman, cuaca, tanah, } \\
\text { air, batu-batuan, dll) } \\
\text { 3.9. Mengenal teknologi } \\
\text { sederhana (peralatan } \\
\text { rumah tangga, peralatan } \\
\text { bermain, peralatan } \\
\text { pertukangan, dll) }\end{array}$ \\
\hline
\end{tabular}




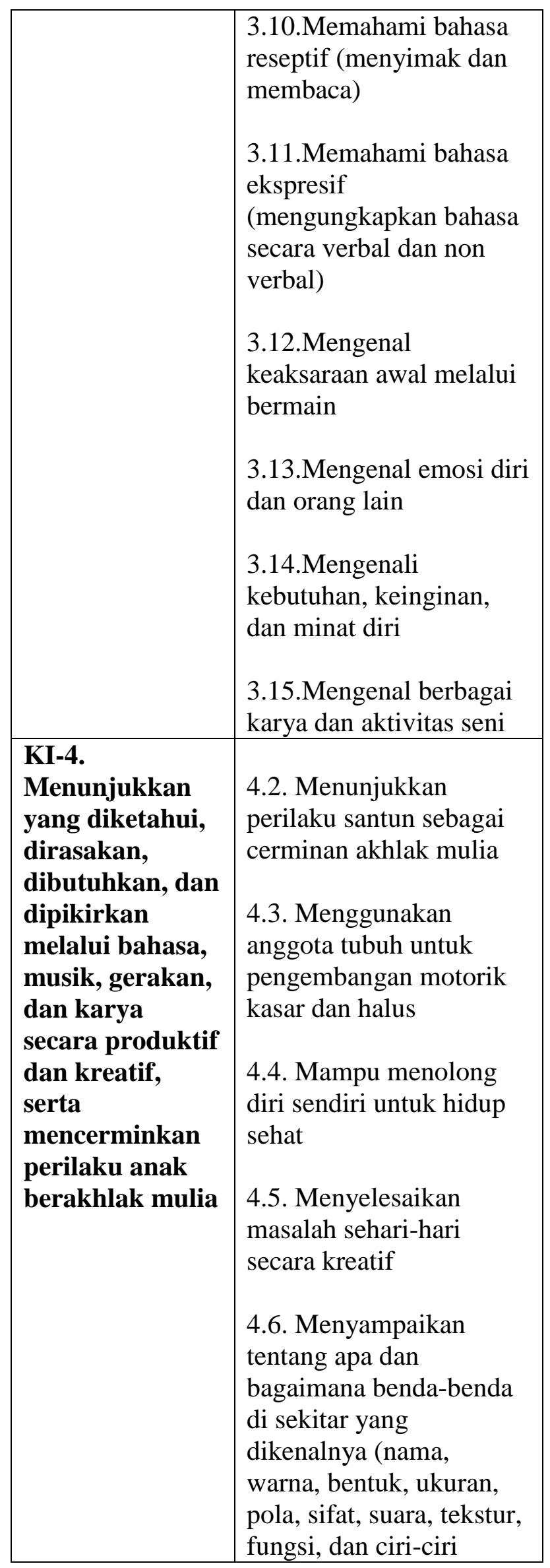

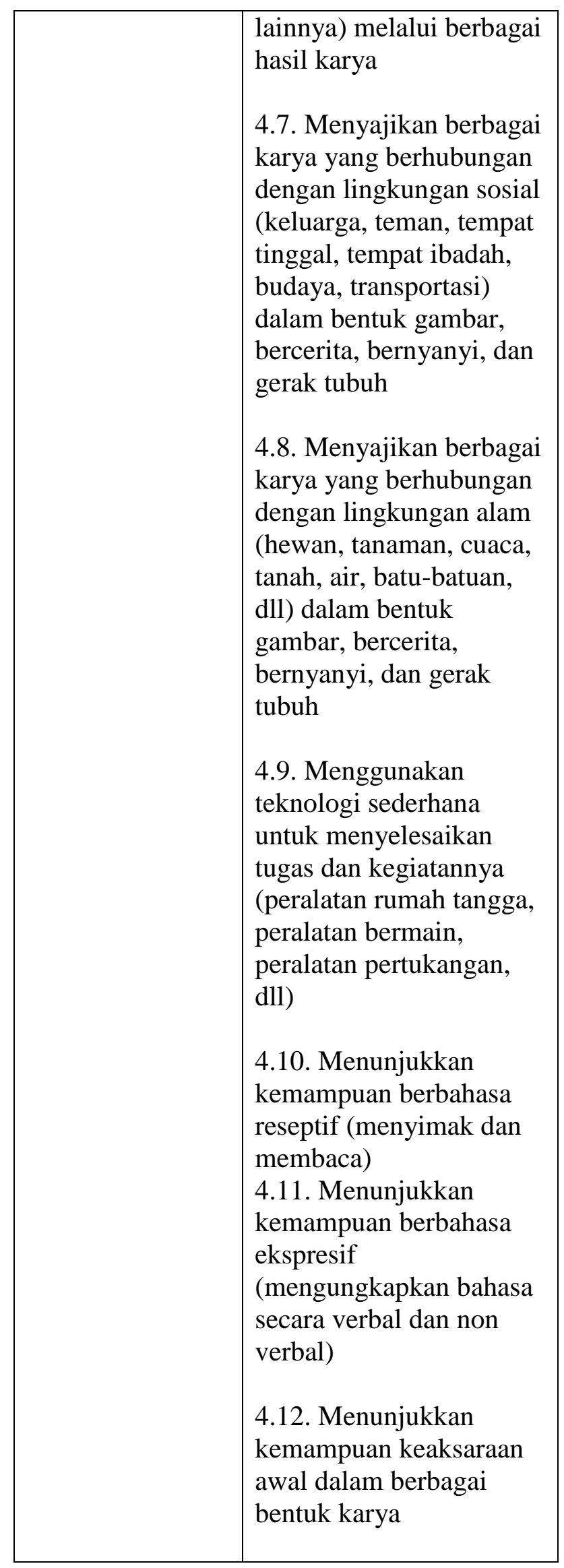




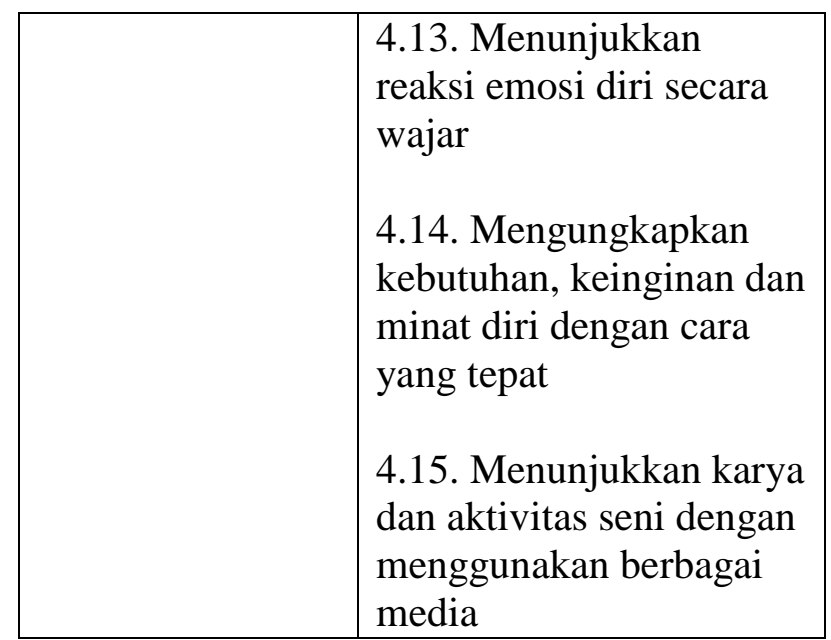

\section{Model Pembelajaran Tematik}

\section{A. Pengertian Model}

Sebelum menjelaskan tentang model pembelajaran Tematik ada baiknya menjelaskan terlebih dahulu tentang Model pembelajaran. Istilah model pembelajaran diambil dari dua suku kata, yaitu model dan pembelajaran. Dimana masing-masing kata tersebut memiliki makna yang berbeda-beda. Menurut Good dan Trafes, model adalah abstraksi dunia nyata atau representasi peristiwa kompleks dalam bentuk naratif, matematis, garfis, dan lambang-lambang lainnya. (Abdullah,2007:82). Sedangkan belajar secara umum diartikan sebagai perubahan pada individu yang terjadi melalui pengalaman dan bukan karena pertumbuhan atau perkembangan tubuhnya atau karakteristik seseorang sejak lahir. Perubahan yang dimaksud perubahan prilaku yang berupa pengetahuan, pemahaman, keterampilan,dan kebiasaan yang baru diperoleh individu.

Trianto mengemukakan Model Pembelajaran adalah kerangka konseptual yang melukiskan prosedur yang sistematis dalam mengorganisasikan pengalaman belajar untuk mencapai tujuan belajar tertentu, dan berfungsi sebagai pedoman bagi para perancang pembelajaran dan para pengajar dalam merencanakan aktifitas belajar mengajar. (Trianto, 2009:22)

Berdasarkan uraian diatas dapat diambil suatu pemahaman bahwa model pembelajaran ialah pedoman untuk membuat perencanaan pembelajaran yang sistematis, guna mencapai tujuan pembelajaran yang telah ditentukan. Jadi Istilah model pembelajaran mempunyai makna yang lebih luas daripada strategi, metode atau prosedur. Model pengajaran memiliki empat ciri khusus yang tidak dimiliki oleh strategi, metode atau prosedur, ciri-ciri tersebut ialah:

1. Rasional teoritis logis yang disusun oleh para pencipta atau pengembangnya.

2. Landasan pemikiran tentang apa dan bagaimana siswa belajar (tujuan pembelajar yang akan diapai)

3. Tingkah laku mengajar yang diperlukan agar model tersebut dapat dilaksanakan dengan berhasil

4. Dan lingkungan belajar yang diperlukan agar tujuan pembelajaran itu dapat tercapai. 


\section{B. Pengertian Tematik}

Tematik/tema adalah pokok pikiran atau gagasan pokok yang menjadi pokok pembicaraan. Selanjutnya dapat dimaknai bahwa tema merupakan alat atau wadah untuk mengedepankan berbagai konsep kepada anak didik secara utuh . tema diberikan dengan maksud menyatukan isi kurikulum dalam satu kesatuan yang utuh, memperkaya pengetahuan anak dan melibatkan beberapa kegiatan pembelajaran untuk memberikan pengalaman yang bermakna pada anak. keterpaduan dalam kegiatan pembelajaran ini dapat dilihat dari aspek proses atau waktu, aspek kurikulum, dan aspek belajar mengajar (Trianto, 2009:22)

Tema yang merupakan sebuah pokok pikiran disampaikan melalui aliran TFP ( term, fact, and principle). Term merupakan informasi umum yang bisa didapatkan anak melalui pengalaman, orang dewasa/guru, dan teman. Informasi yang diberikan atau dialirkan kepada anak hendaklah merupakan keadaan atau peristiwa yang merupakan kenyataan atau suatu hal yang benar-benar ada atau terjadi (Fact), dan sesuatu yang benar dan menjadi pokok dasar berpikir atau bertindak (principle). Kurikulum pengajaran dengan tema dan TFP untuk memberikan pengajaran dengan total guna menciptakan pengajaran yang holistik (menyeluruh), pada program awal terpadu untuk anak-anak, dan kurikulum tema mempunyai karakter tersendiri menurut para ahli (Mukhtar Latif, 2014:48).

Menurut Dewey, kurikulum berhubungan dengan hidup yang sesungguhnya. Oleh karena itu, tema dipilih berdasarkan materi kehidupan yang mengalir melalui kurikulum yang disusun. Menurut Hendrik (1986), pengajaran melalui tema menolong anak untuk membangun "an overll sense of direction and consolidation" dalam pembelajarannya. Adapun menurut Obsorn (1983), melalui program yang berdasrkan tema, anak dapat membangun hubungan antara potongan-potongan (fragment) informasi menjadi bentuk konsep yang abstrak dan lebih kompleks.

Kurikulum yang disusun dalam "tema" membuat anak melibatkan dirinya didalam semua arena yang mereka pelajari dan menjadikan mereka untuk selalu tertarik pada suatu topik dengan sikap ingin tahu. Dalam hal ini guru harus mampu mengorganisasikan antara pikiran dan rencana (planning), sehingga dapat memilih aktifitas yang bermanfaat untuk anak. dengan cara guru mengumpulkan semua data dan di organisasikan sebagai dasar perencanaan oleh mereka, dimana hal ini berguna untuk menjaga dan meningkatkan akurasi informasi yang mendukung anak. 
Pembelajaran materi harus dan perkembangan siswa. (Rusman, berasal dari suatu pengalaman yang dekat 2012:254)

dengan kehidupan anak. tema selain merupakan bingkai dari materi pembelajaran yang sudah direncanakan, juga dibutuhkan guru guna menarik perhatian anak untuk mereka bisa fokus terhadap:

1. Karakteristik dan detail dari topik yang spesifik

2. Menyebutkan dan mendeskripsikan suatu objek dan prosesnya.

3. Memberikan detail bagaiman kerja sesuatu

4. Bertanya serta menjawab pertanyaan anak

Tema berfungsi sebagai bingkai perencanaan pembelajaran yang lebih terarah. Artinya, tema ini akan menjaga agar seluruh materi yang telah disusun tidak ada yang tercecer pada waktu pelakasanaan atau jangan sampai materi yang tidak direncanakan ikut masuk dalam pelaksanaan.

Sementara Model Pembelajaran Tematik adalah salah satu model dalam pembelajaran terpadu ( integrated instruction) yang merupakan suatu sistem pembelajaran yang memungkinkan siswa, baik secara individual maupun kelompok, aktif menggali dan menemukan konsep serta prinsip-prinsip keilmuwan secara holistik, bermakna, dan autentik. Pembelajaran terpadu berorientasi pada praktik pembelajaran yang sesuai dengan kebutuhan

Martiono (2011) mengatakan pengertian pembelajaran Tematik adalah Pembelajaran Terpadu yang menggunakan Tema untuk mengaitkan beberapa mata pelajaran sehingga memberikan pengalaman bermakna bagi peserta didik. Selain itu Yuliani Nurani mengatakan pembelajaran tematik merupakan suatu strategi pembelajaran yang melibatkan beberapa bidang pengembangan untuk memberikan pengalaman yang bermakna kepada anak. keterpaduan dalam pembelajaran ini dapat dilihat dari aspek proses atau waktu, aspek kurikulum, dan aspek belajar. Pembelajarn tematik dibelajarkan pada anak karena pada umumnya mereka masih melihat sesuatu sebagai satu keutuhan (holistik) perkembangan fisiknya tidak pernah dapat dipisahkan dengan perkembangan mental, sosial, dan emosional. (Yuliani,2015:24)

Berdasarkan uraian diatas ditarik kesimpulan bahwa Model Pembelajaran Tematik adalah suatu model Pembelajaran Terpadu yang memungkinkan siswa maupun secara kelompok, aktif menggali dan menemukan konsep serta prinsip keilmuawan secara holistik (keutuhan) dan bernakna berangkat dari satu tema/topik tertentu sesuai dengan pengalaman dan kehidupan anak dan kemudian dielaborasi dari berbagai aspek atau ditinjau dari berbagai perspektif 
perkembangan terdiri dari 6 perkembangan yaitu Kognitif, bahasa, sikap, spiritual, keterampilan dan seni.

\section{Landasan Pendekatan Model Pembelajaran Tematik}

Sebagaimana yang dijelaskan pusat kurikulum Balitbang Depdiknas adalah Landasan Pembelajaran Tematik mencakup landasan filosofis, landasan psikologis dan landasan Yuridis. ${ }^{1}$ Berikut penulis jelaskan lebih rinci.

1. Landasan filosofis, pembelajaran yang menggunakan pendekatan Tematik sangat dipengaruhi oleh tiga aliran filsafat yaitu : progresivisme, konstruktivisme, dan humanisme. Aliran progresivisme memandang aliran proses pembelajaran perlu ditekankan pada pembentukan kreatifitas, pemberian sejumlah kegiatan, suasana yang alamiyah (Natural), dan memperhatikan pengalaman siswa. Aliran konstruktivisme melihat pengalaman langsung siswa (direct experience) sebagai kunci dalam pembelajaran.menurut aliran ini, pengetahuan tidak dapat ditranfer begitu saja dari seorang guru kepada anak, tetapi harus diintepretasikan sendiri oleh masing-masing siswa. Aliran

${ }^{1}$ Pusat Kurikulum, Model Pendekatan Tematik Kelas Awal Sekolah Dasar, (Jakatarta : Balitbang Depdiknas, 2006), hlm.9. humanisme melihat siswa dari segi keunikan/kekhasannya, potensinya, dan motivasi yang dimilikinya.

2. Landasan Psikologi, Pembelajaran yang menggunakan pendekatan tematik berkaitan dengan psikologi perkembangan peserta didik dan psikologi belajar. Psikologi pembelajaran diperlukan terutama dalam menentukan isi/materi pembelajaran tematik yang diberikan kepada siswa agar tingkat keluasan dan kedalamannya sesuai dengan tahap perkembangan peserta didik.pembelajaran memberikan kontribusi dalam hal bagaimana isi/materi pemebelajaran tematik tersebut disampaikan kepada siswa dan bagaimana pula siswa harus mempelajarinya.

3. Landasan Yuridis, pembelajaran dengan pendekatan tematik berkaitan dengan berbagai kebijakan atau peranturan yang mendukung pelaksanaan pembelajaran tematik disekolah dasar. Landasan yuridis tersebut adalah UU No. 23 Tahun 2002 tentang perlindungan anak yang menyatakan bahwa setiap anak berhak memperoleh pendidikan dan pengajaran dalam rangka pengembangan pribadinya dan tingkat kecerdasannya sesuai dengan minat dan bakatnya (pasal 9). UU No. 20 
Tahun 2003 tentang sistem Pendidikan Nasional menyatakan bahwa setiap peserta didik pada setiap satuan pendidikan berhak mendapatkan pelayanan pendidikan sesuai dengan bakat, minat, dan kemampuannya.

\section{Teori Belajar yang Melandasi Pembelajaran Tematik}

Berangkat dari beberapa Teori para Tokoh yang melandasi Pembelajaran Tematik, antara lain teori Jean Peaget, Teori Vygotsky,Teori Bandura dan terakhir Teori Bruner, diawali dengan Teori perkembangan Jean Peaget, Menurutnya seorang anak maju melalui empat tahap perkembangan kognitif, antara lahir dan dewasa, yaitu: tahap sensorimotor, pra operasional, operasi kongkrit, dan operasi formal. Tiap tahap ditandai dengan munculnya kemampuankemampuan intelektual baru yang memungkinkan orang memahami dunia dengan cara yang semakin kompleks.

Perkembangan tergantung pada sejauh mana anak aktif berinteraksi dengan lingkungan. Hal ini menentukan proses perkembangan kognitif anak. adaptasi lingkungan dilakukan melalui proses asimilasi dan akomodasi, serta enkuilibrasi. Asimilasi merupakan pengintrepretasian pengalaman-pengalaman baru dalam hubungannya dengan skema-skema yang telah ada. Sedangkan akomodasi adalah pemodifikasian skema-skema yang ada untuk mencocokkannya dengan stuasi-stuasi baru .proses kesetimbangan, kebingungan, kebimbangan antara pemahaman yang telah ada dan pengalaman-pengalaman baru disebut enkuilibrasi.

Pembelajaran pada dasarnya tergantung pada proses enkuilibrasi ini. Pada saat anak mengalami kebingungan, bimbang, ketidakseimbangan pemahamannya,maka pada saat inilah terjadi proses belajar. Guru dapat mengambil keuntungan equilibrasi dengan menciptakan situasi yang mengakibatkan ketidakseimbangan dan oleh karena itu pula menyebabkan timbulnya keingintahuan siswa.

Piaget yakin bahwa pengalaman-pengalaman fisik dan manipulasi lingkungan belajar yang memadai agar siswa dapat menemukan pengalaman-pengalaman nyata dan terlibat langsung dengan alat media.

berlanjut kepada Teori Vygotsky, yang mana menurutnya bahwa pembelajaran terjadi apabila anak bekerja atau belajar menangani tugas-tugas yang belum dipelajari namun tugas-tugas itu masih berada dalam jangkauan kemampuannya atau tugas-tugas tersebut berada dalam Zone of proximal development.

Teori Bandura, yang mana menurutnya seseorang belajar melalui pengamatan secara efektif, mengingat serta mengamati tingkah laku orang lain (model) hasil pengamatan itu kemudian dimantapkan 
dengan cara menghubungkan pengalaman baru dengan pengalaman sebelumnya atau mengulang-ngulang kembali. Dengan jalan ini memberi kesempatan kepada orang tersebut mengekspresikan tingkah laku yang dipelajarinya.

Terakhir adalah Teori Bruner, menurut nya belajar akan lebih bermakna bagi siswa jika mereka memusatkan perhatiannya untuk memahami struktur materi yang dipelajari. (Anisatul, 2013:189)

\section{E. Karakteristik model pembelajaran tematik}

Pembelajaran tematik memiliki karakteristikkarakteristik sebagai berikut:

\section{Berpusat pada siswa}

Pembelajaran tematik berpusat pada siswa (student centered). Hal ini sesuai dengan pendekatan belajar modern yang lebih banyak menempatkan siswa sebagai subjek belajar, sedangkan guru lebih banyak berperan sebagai fasilitator, yaitu memberikan kemudahan-kemudahan pada siswa untuk melakukan aktifitas belajar.

\section{Memberikan pengalaman langsung}

Pembelajaran tematik dapat memberikan pengalaman langsung pada siswa (direct experiences). Dengan pengalaman langsung ini, siswa dihadapkan pada sesuatu yang nyata (konkret) sebagai dasar untuk memahami hal-hal yang lebih abstrak.

3. Pemisahan mata pelajaran tidak begitu jelas
Dalam pembelajaran tematik pemisahan antarmata pelajaran menjadi tidk begitu jelas. Fokus pembelajaran diarahkan pada pembahasan tema-tema yang paling dekat berkaitan dengan kehidpan siswa.

4. Menyajikan konsep dari berbagai mata pelajaran

Pembelajaran tematik menyajikan konsepkonsep dari berbagai mata pelajaran dalam suatu proses pembelajaran. Dengan demikian, siswa dapat memahami konsepkonsep tersebut secara utuh. Hal ini diperlukan untuk membantu siswa dapat memahami konsep-konsep tersebut secara utuh. Hal ini doperlukan untuk membantu siswa dalam memecahkan masalah-masalah yang dihadapi dalam khidupan sehari-hari.

5. Bersifat fleksibel

Pembelajaran tematik bersifat luwes (fleksibel) dimana guru dapat mengaitkan bahan ajar dari satu mata pelajaran dengan mata pelajaran yang lainnya, bahkan mengaitkannya dengan kehidupan siswa dan keadaan lingkungan dimana sekolah dan siswa berada.

\section{F. Model Pembelajaran Tematik}

Menurut Fogarty dalam Sukayati apabila ditinjau dari sifat materi dan cara memadukan konsep keterampilan dan unit tematisnya ada 10 model pembelajaran terpadu, seperti: penggalan (fragmented), keterhubungan (connected), sarang (nested), pengurutan (sequenced), irisan (shared), jaring laba-laba 
(webbed), bergalur (treaded), terpadu (integreted), terbenam ( immersed), dan jaring kerja (networked). Dari kesepuluh model pembelajaran terpadu diatas ada tiga model yang dianggap layak dan sesuai yang dapat dikembangkan dan mudah dilaksanakan di pendidikan anak usia dini. Ketiga model tersebut antara lain:

a. Model hubungan atau terkait ( connected model)

Model pembelajaran ini menghubungkan pembelajaran yang eksplisit didalam suatu mata pelajaran yaitu menghubungkan satu topik ke topik yang lain, satu konsep ke konsep yang lain, satu keterampilan ke keterampilan yang lain dan satu tugas ke tugas yang berikutnya. Pada model pembelajaran ini kunci utamanya adalah adanya suatu usaha sadar untuk menghubungkan suatu bidang kajian dalam suatu disiplin ilmu. Keunggulan dari pembelajaran ini adalah siswa memperoleh pengetahuan akan sangat mudah karena konsep-konsep pokok dikembangkan terus menerus.

\section{Gambar 4. Model hubungan atau terkait}

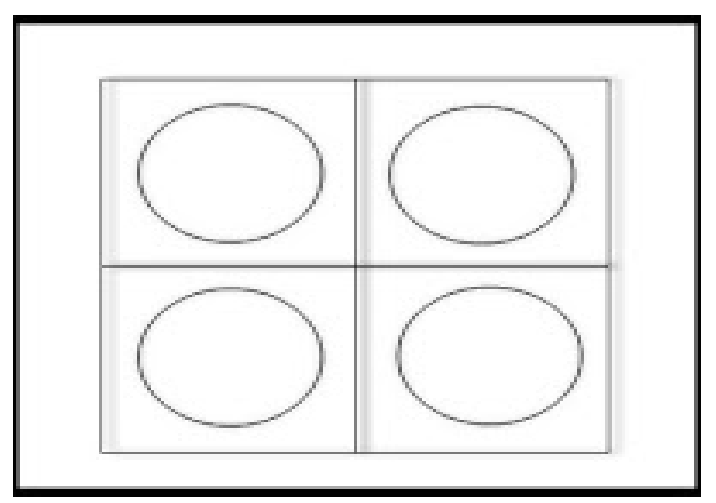

b. Model jaringan laba-laba atau terjala (webbed model)

Model pembelajaran ini pada dasarnya menggunakan pendekatan tematik. Pembelajaran ini pengembangannya dimulai dari menentukan tema tertentu. Tema yang ditetapkan dapat ditetapkan antara guru dan siswa atau sesama guru. Setelah tema disepakati maka dilanjutkan dengan pemilihan sub-sub tema dengan memperhatikan kaitannya dengan antar mata pelajaran. Berdasarkan susb-sub tema ini direncanakan aktifitas belajar yang dilakukan siswa. Keuntungan model pembelajaran terpadu ini adalah diperoleh pandangan hubungan yang utuh tentang kegiatan dari ilmu yang berbeda-beda.

\section{Gambar 5. Model jaring (webbed model)}

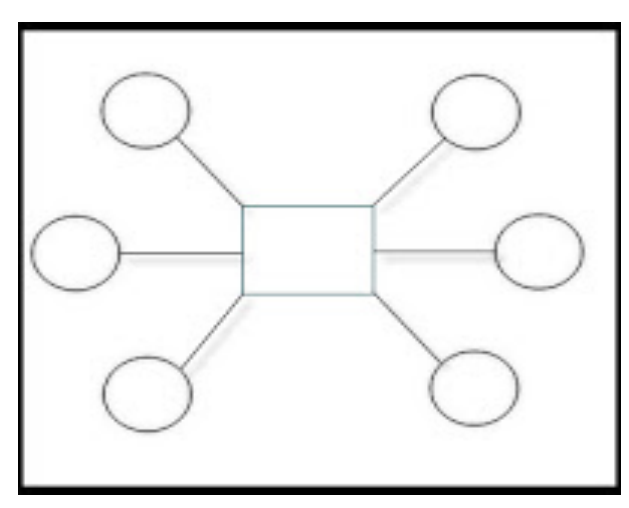

\section{c. Model terpadu (integrated model)}

Model pembelajarn terpadu ini menggunakan pendekatan antar matapelajaran. Model ini diusahakan dengan menggabungkan beberapa matapelajaran yaitu dengan menetapkan prioritas dari kurikulum dan menemukan 
keterampilan, konsep, dan sikap saling tumpang tindih didalam matapelajaran.

Gambar 6. Model Integrated

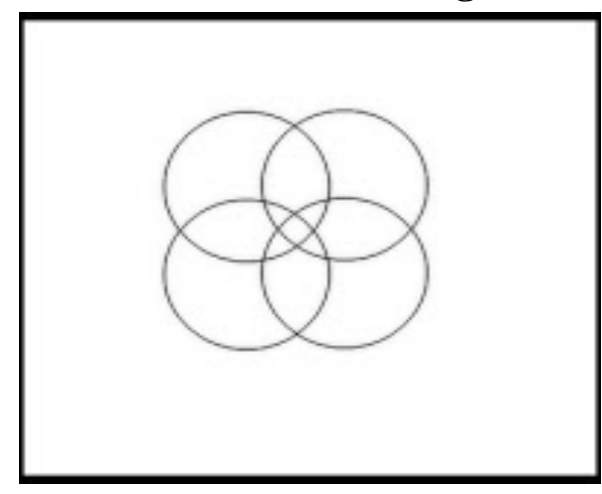

Berdasarkan penjelasan tiga model pembelajaran terpadu diatas, adapun model yang peneliti maksudkan adalah model jaringan laba-laba atau terjala (webbed model), dimana dengan model ini nanti peneliti menentukan suatu tema kemudian memilih berbagai kosa kata yang terkait dengan tema tersebut. Peneliti memilih model ini dengan alasan model terjala atau laba-laba (webbed model) lebih mudah mengkonsepkan tema dengan beberapa kosa kata dan lebih mudah di pahami oleh anak usia dini. (Abdul 2014:76)

3. Implimentasi Pengembangan Model Tematik Dalam Pembelajaran Anak Usia Dini

Mengembangkan Tema dalam

Pembelajaran berhubungan dengan delapan domain anak yang dikembangkan antara lain : 1) Estetik (Estetik), 2) Afeksi (Afefective Development), 3) Kognisi (Cognition), 4) Bahasa (Languange), 5) Fisik (Phisical), 6) Sosial (Social Development), 7) Pembangunan (Contruction), 8) Bermain Pura-pura (Pretend Play). (Latif, 2014:50)

Tema-tema dapat disusun atau dibangun dengan cara sebagai berikut:

\section{Pilihan pertama}

Memberikan anak dengan gambaran umum tentang 'Tema” selama 2-3 minggu.

\section{Pilihan Kedua}

Minggu pertama memberikan pengenalan umum tentang "Tema"

Minggu kedua sampai minggu keempat: fokus pada bagian khusus

Contoh pada "Tema Tanaman"

- Minggu pertama : pengenalan umum tentang tanaman

- Minggu kedua : fokus pada akar dan batang

- Minggu ketiga : fokus pada daun

- Minggu ke empat : Fokus pada bunga dan biji. 


\section{a. Pembuatan Tema dalam Bentuk Bagan}

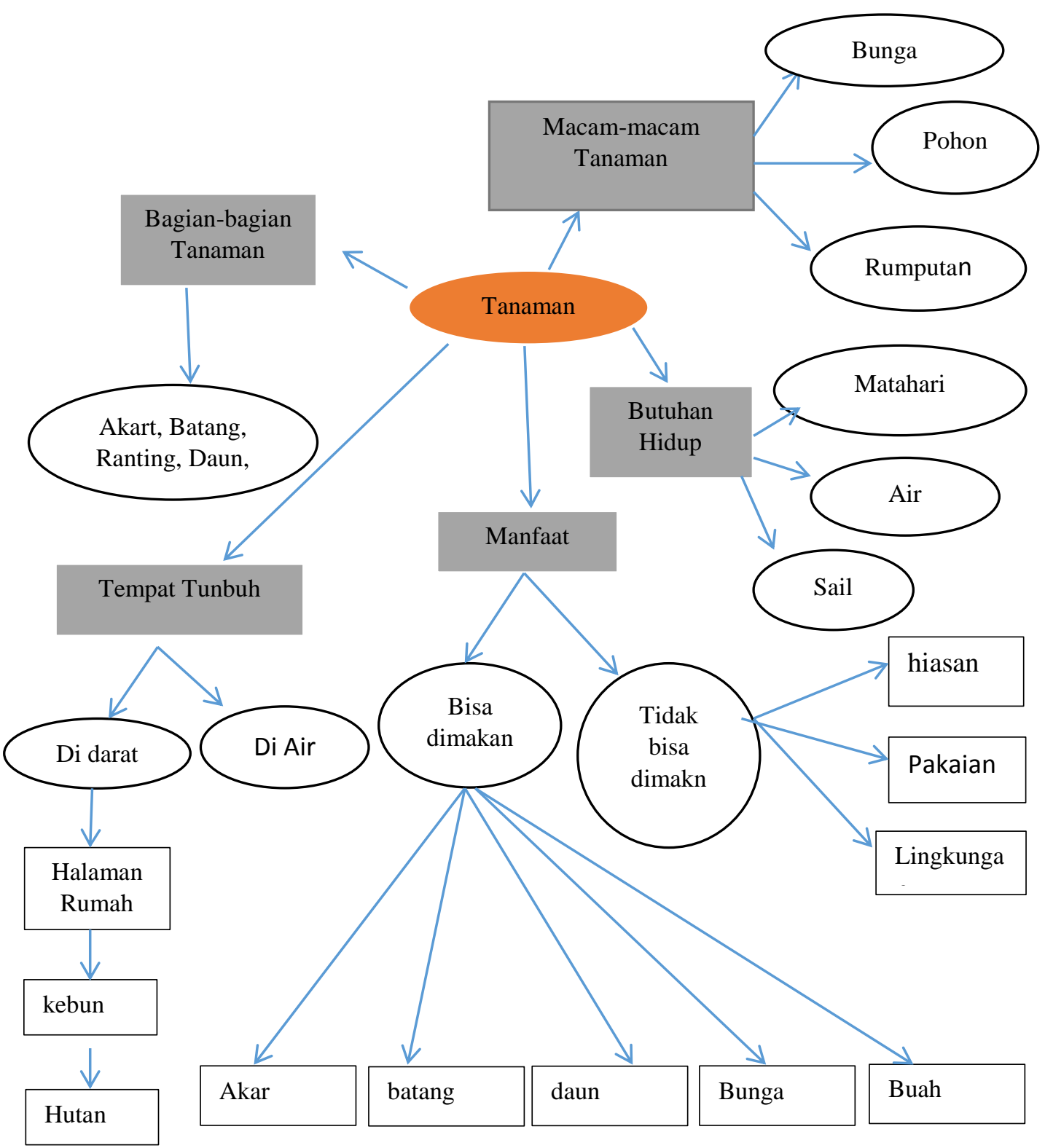

Setiap tema merupakan bagian dari bunga, memeriksa daun-dun yang kering di lingkungan alam anak yang mempunyai halaman, mencium bau bunga atau rumput. tujuan dan rencana dalam pelaksanaan. Melalaui beratus-ratus pengalaman sehariMisalnya seperti tema bagan diatas, "Tema hari anak akhirnya akan sadar telah belajar Tanaman”. Anak kontak dengan dengan tentang tanaman. tanaman setiap hari, seperti memungut bunga- 


\section{b. Identifikasi Tema kedalam Kegiatan Minggu (Tema : Tanaman, Sub Tema: Padi di Sawah)}

\begin{tabular}{|c|c|c|}
\hline $\begin{array}{l}\text { Kognitif } \\
\text { - Mengelompok } \\
\text { kan padi yang } \\
\text { matang dan } \\
\text { muda } \\
\text { - Mengamati padi } \\
\text { disawah } \\
\text { - Mengamati } \\
\text { tumbuh } \\
\text { kembang padi di } \\
\text { sawah } \\
\text { - Meraba gabah } \\
\text { padi } \\
\text { - Membedakan } \\
\text { nasi biasa dan } \\
\text { nasi goreng } \\
\text { - Menimbang Padi } \\
\text { - Mengelompok } \\
\text { kan berdasarkan } \\
\text { warna padi yang } \\
\text { matang dan } \\
\text { masih muda }\end{array}$ & $\begin{array}{l}\text { Nilai-nilai Agama dan Moral } \\
\text { - Menceritakan "Padi di } \\
\text { Sawah ciptaan Tuhan". } \\
\text { (NAM) } \\
\text { - Menyanyi “Ciptaan } \\
\text { Tuhan". (NAM) } \\
\text { - Melaksanakan Ibadah } \\
\text { untuk "mensyukuri } \\
\text { ciptaan Tuhan".(NAM) } \\
\uparrow\end{array}$ & $\begin{array}{l}\text { Bahasa } \\
\text { - Mendengar dan } \\
\text { menceritakan } \\
\text { Kembali "Padi di } \\
\text { Sawah". (B) } \\
\text { - Mengurutkan dan } \\
\text { menceritakan } \\
\text { gambar seri } \\
\text { perkembang } \\
\text { biakan padi (B) } \\
\text { - Syair teladan } \\
\text { "sifat-sifat Padi" } \\
\text {-Bermain Peran } \\
\text { Fisik/ Kesehatan } \\
\text { Fisik } \\
\text { - Makan makanan } \\
\text { yang } \\
\text { berkarbohidrat } \\
\text { "Nasi". } \\
\text { - Mengukur tinggi } \\
\text { badan anak “yang } \\
\text { suka makan nasi } \\
\text { dan tidak suka } \\
\end{array}$ \\
\hline $\begin{array}{l}\text { Fisik / Motorik } \\
\text { Kasar } \\
\text { - Berjalan di } \\
\text { pematangan } \\
\text { sawah } \\
\text {-Menanam padi di } \\
\text { sawah }\end{array}$ & \multicolumn{2}{|c|}{$\begin{array}{l}\text { Fsik / Motorik Halus } \\
\text { - Menggambar padi di sawah } \\
\text { - Melipat dan menggunting padi } \\
\text { - Membentuk berbagai bentuk dengan balok "petakan } \\
\text { - } \text { sawah" } \\
\text { - Bermaian dengan alat perkusi "botol dan sawah" } \\
\text { - Membuat Maket "padi di sawah" } \\
\text { - Membentuk dari koran bekas "padi di sawah" }\end{array}$} \\
\hline
\end{tabular}




\section{c. Identifikasi tema dalam rencana kegiatan Harian}

Kelompok

Semester/Minggu

Tema/ Sub Tema

Hari, Tanggal

Waktu
:A

$: \mathrm{I} / 1$

:Tanaman/ Padi di Sawah

:Senin, 23 juni 2015

$: 07.30-10.15$

\begin{tabular}{|c|c|c|c|c|}
\hline \multirow[t]{2}{*}{ Indikator } & \multirow[t]{2}{*}{ Kegiatan Pembelajaran } & \multirow[t]{2}{*}{$\begin{array}{c}\text { Alat / Sumber } \\
\text { Belajar }\end{array}$} & \multicolumn{2}{|c|}{$\begin{array}{c}\text { Penilaian } \\
\text { Perkembangan } \\
\text { pesrta }\end{array}$} \\
\hline & & & Alat & Hasil \\
\hline $\begin{array}{l}\text {-Mengikuti aturan } \\
\text { (NAM) } \\
\text { - Berdo'a sebelum } \\
\text { melakukan kegiatan. } \\
\text { - Mendengar cerita } \\
\text { sederhana } \\
\text { - Berjalan di atas } \\
\text { pematangan sawah. } \\
\text { - Mencerita kembali } \\
\text { isi cerita yg pernah } \\
\text { didengar } \\
\text { - Membilang dan } \\
\text { menunjuk benda 1- } \\
\text { 10 } \\
\text {-Menunjuk kumpulan } \\
\text { benda yang sama } \\
\text { jumlahnya lebih } \\
\text { banyak dan sedikit } \\
\text { - Menunjuk sebanyak } \\
\text { - banyak tumbuhan } \\
\text { menurut jenisnya }\end{array}$ & $\begin{array}{l}\text { Upacara bendera } \pm 15 \text { menit } \\
\text { I. Kegiatan Awal } \pm \mathbf{3 0} \text { menit } \\
\text { (klasikal) } \\
\text {-Bernyanyi, Salam dan } \\
\text { Berdo'a } \\
\text {-Menceritakan "padi" sebagai } \\
\text { ciptaan Tuhan } \\
\text { - Pemberian Tugas : Berjalan } \\
\text { diatas pematangan sawah. }\end{array}$ & $\begin{array}{l}\text {-Pematangan } \\
\text { sawah berupa } \\
\text { titian } \\
\text {-Buku cerita, } \\
\text { buku gambar } \\
\text { serta crayon }\end{array}$ & $\begin{array}{l}\text {-Observasi } \\
\text { - Observasi } \\
\text { - } \\
\text { Percakapan }\end{array}$ & \\
\hline
\end{tabular}




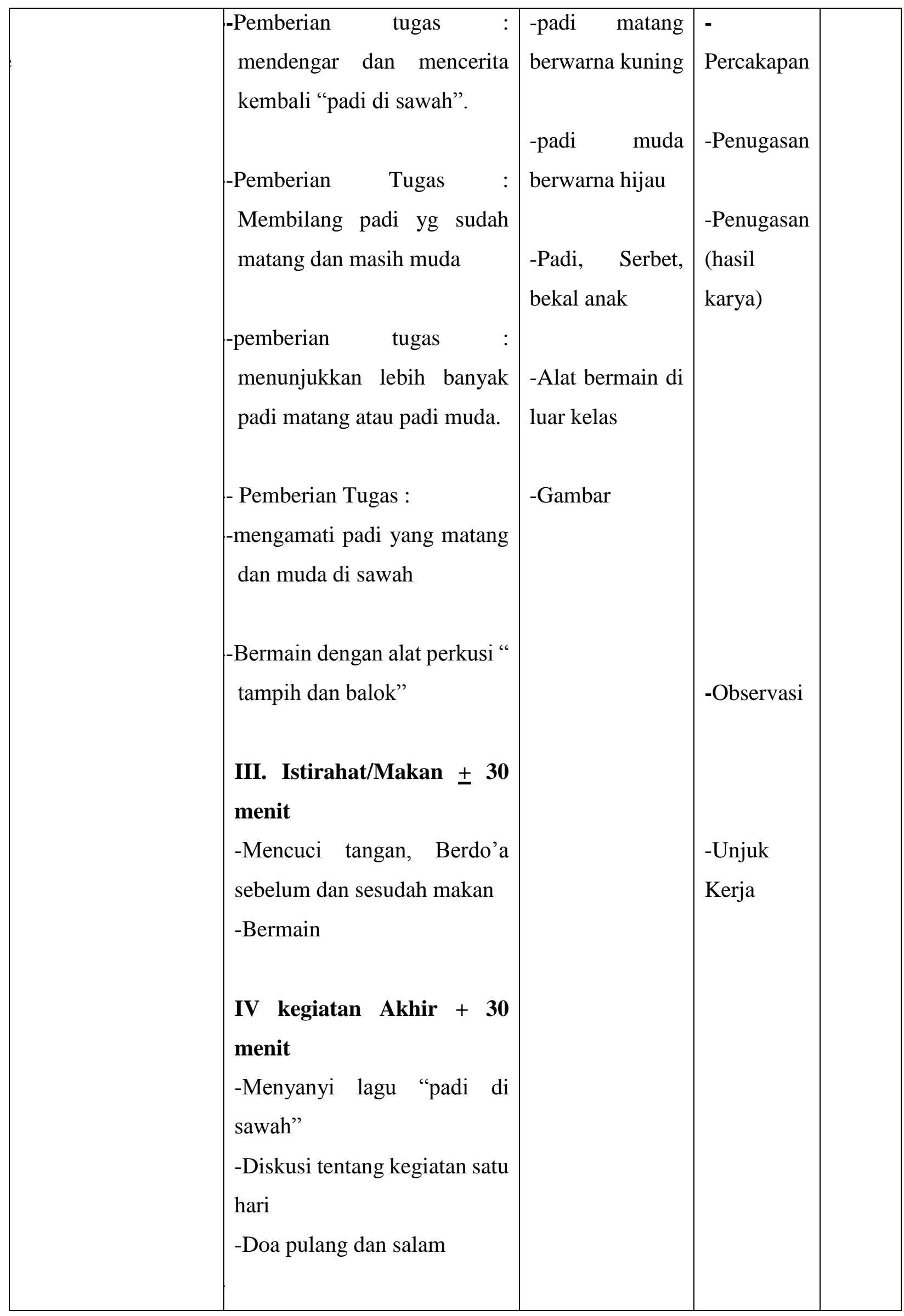




\section{Kesimpulan}

Pembelajaran tematik merupakan suatu strategi pembelajaran yang melibatkan beberapa bidang pengembangan untuk memberikan pengalaman bermakna kepada anak. Keterpaduan pembelajaran ini dapat dilihat dari aspekosional, proses atau waktu, aspek kurikulum, dan pembelajarannya. Pembelajaran tematik diterapkan pada anak usia dini karena pada umumnya mereka masih melihat segala sesuatu sebagai satu keutuhan (holistic). Perkembangan fisiknya tidak pernah dapat dipisah dengan perkembangan mental, kognitif, sosial, dan emosional sehingga kegiatan pembelajaran kesemua aspek perkembangan tersebut harus distimulasi secara bersamaan atau terintegrasi satu dan lainnya.

Anak usia TK/RA berada pada tahapan operasi konkret. Pada rentang usia tersebut anak mulai menunjukkan prilaku belajar seperti mulai memandang dunia secara objektif, bergeser dari satu aspek situasi ke aspek lain secara reflektif dan memandang unsur-unsur secara serentak, mulai berpikir secara operasional, menggunakan cara berpikir operasional untuk mengklasifikasikan benda-benda, membentuk dan menggunakan keterhubungan aturan-aturan, prinsip ilmiyah sederhana, dan mnggunakan hubungan sebab akibat dan memahami konsep substansi volume zat cair, panjang, lebar, luas dan berat.

Memerhatikan tahapan perkembangan berpikir tersebut, kecenderungan belajar anak usia TK/RA memiliki 3 ciri, yaitu: Konkret, integratif dan hierarkis. Bedasarkan sifat dan karakter anak usia dini, maka pembelajaran di TK/RA bersifat tematik yang dilakukan secara integratif, artinya bahwa pembelajaran dilakukan dengan metode tunggal. Itulah sebabnya, model pembelajaran yang dikenalkan adalah bersifat paduan (integral). 


\section{Daftar Pustaka}

Lathief, Mukhtar, Orientasi Pendidikan Anak Usia Dini, Jakarta : Kencana, 2014

Majid, Abdul, Pembelajaran Tematik Terpadu, Bandung : PT Remaja Rosdakarya, 2014

Nurani, Yuliani, Implementasi Kurikulum 2013 Pendidikan Anak Usia Dini, Bekasi : Yayasan Yebefo, 2014

Peraturan Menteri Pendidikan dan Kebudayaan No. 146 tahun 2013 lampiran I tentang Kompetensi Dasar dan Kompetensi Inti Pendidikan Anak Usia Dini

Peraturan Menteri Pendidikan dan Kebudayaan No. 146 tahun 2014 bab 1 pasal 1 tentang Sistem Pendidikan Nasional

Rusman, Model-model Pembelajaran Mengembangkan Profesionalisme Guru, Jakarta: PT Raja Grafindo Persada, 2012

Trianto, Mendesain Model Pembelajaran Inovatif-Progresif, Jakarta : Kencana Prenada Media Group, 2009 